\title{
Technique-economical Viability of Repowering of Small Hydroelectric Power Plant considering the Social Insert and Environmental Preservation.
}

\author{
Oscar A. Maldonado ${ }^{1}$, Paulo A. Panunzio, Dinara F. Silva ${ }^{2}$, José Luz Silveira \\ Departamento de Engenharia Elétrica \\ Universidade Estadual Paulista "Julio de Mesquita Filho" \\ Av. Ariberto Pereira da Cunha, 333 \\ CEP: 12516-410 - Guaratinguetá - SP, Brasil. \\ Phone: +55 (012) 3123-2832 - Fax:+55 (012) 3123-2866 \\ (1) oscarama@feg.unesp.br, ${ }^{(2)}$ dinara@feg.unesp.br
}

\begin{abstract}
The increasing growth of electrical energy demand, associated with an increase in the costs of energy production and the care related to environmental and social questions lead the planning of the world energetic sector to set a strategy for a more efficient utilization of the existing production sources. This work presents a case study of repowering a Small Hydroelectric Power Plant (SHPP), to demonstrate that this kind of enterprise is feasible in offering an augment of electrical energy to the system so to supply any future demand. Based on the statistics of a river hydraulic potential supplying the plant, one verifies the possibility of raising the capacity of electrical power generation of a water fillet in approximately $75 \%$. The presented analysis of the technical-economical viability does not only consider the value of the equipments and the current costs of the electrical energy, but is also an effort to incorporate the various environmental and social benefits which can be obtained by the repowering of a SHPP, with emphasis to the generation and commercialization of carbon credits which enable the reduction of the investment paying-off time, making this enterprise more attractive from an economical, social and environmental standpoints.
\end{abstract}

\section{Keywords}

Repowering, Small Hydroelectric Power Plant, Electrical Generation Capacity, Carbon Credit, Sustained Development, Social Insertion

\section{Introduction}

The hydraulic power plants constitute the basis of the Brazilian energetic generation system, answering for about $80 \%$ of the electrical offering. This raised participation has been reached in the latest 30 years by indiscriminate constructions of large power plants, bringing serious social and environmental problems. At the present time, the rearrangement of the national energetic matrix is oriented by the lack of public resources to invest in great enterprises, the exhaustion of the hydraulic resources near the consumption centers and https://doi.org/10.24084/repqj04.293 by the negative social-environmental impact that the projects can cause. The country's economical development has provided an accelerated growth of electrical power consumption and, therefore, the risks of a possible future crisis in the energetic sector can not be discarded. The actual challenge is to find efficient alternatives, so to obtain electrical energy profits in the country, reducing the present necessity of expanding the power generation in order to supply, in an ensured manner, any expected future demand.

In this context, the small and medium waterflows represent an important generation option, presenting intrinsic advantages in reducing the eventual socialenvironmental negative effects caused by large utilizations. The small hydroelectric power plants (SHPP) present higher viability due to their reduced costs, less implementation time and investment ripening and to the benefits that the present incentive legislation offers, such as the permission to reward the cities and states by the use of their water resources; the disposition of the electrical concessionaires to buy surplus energy generated by the self-producers, besides allowing the access to their long distance power lines [1], [2]. Another important aspect to be considered is that the SHPPs are near the consumption centers, increasing the offering of energy of the electrical system with significant reduction of costs and losses of energy caused by power lines, which faces the principles of Distributed Generation. In Brazil, a large quantity of SHPPs was built between 1930 and 1940, which places the mean age of installations circa 57 years old [1]. The existence of a large number of such power plants demonstrates the opportunity to endeavor investments in this area, the main focus being the repowering of the SHPPs in operation or presently out of service. According to ANEEL (Brazilian Regulatory Commission for Electrical Energy), there are about 233 SHPPs in operation and 600 SHPPs out of service, totaling approximately $1.500 \mathrm{MW}$ installed power [3] which, once being repowered, will provide a greater offering of energy to the electrical sector in Brazil contributing, by the same time, to the economical, social 
and environmental sustenance by means of an increase of utilization of sustainable energy in relation to the total consumption of electricity in the country.

Nowadays, new hydroelectric projects are facing great difficulties by force of severe environmental laws. Many projects are inviable due to their aggressive impacts caused to the environment, such as the beginning or acceleration of erosion process to the reservoir banks, a change in the water quality of the reservoir caused by the organic decomposition which favors the emission of greenhouse gases (GHG), a reduction of the water oxygen concentration, compromising most aquatic species and generating harmful compounds to human health. The construction of a dam impacts on some fish migratory route and causes flooding of extended agricultural areas, historical sites and environmental reserves. An important social impact caused by the construction of dams is the compulsive displacement of riverside populations promoted by the plant installation work which, in many cases, is followed by derisive financial compensation, sometimes inexistent and the population displacement process not always guarantee the maintenance of the previous living conditions [1], [4].

If instead of constructing new power plants, there were the repowering and reactivation of the existing power plants, the offering of the electrical energy system would raise with less or even inexistent negative impacts. Considering that plants to be repowered are already installed for more than 30 years, most of the impact has already being absorbed by the boundary so that the nature is readapted to the power plant environment, the emission of greenhouse gases is practically null and there is no need to compulsively remove the riverside populations. In case there is no interference on the reservoir level, any hypothesis of new erosion process to the lake banks are discarded, as well of new organic decomposition that could affect the water quality and flooding of cultivated land, native forest amongst other aspects. Power plant repowering projects can create expectations, multiply local authority tax collect, create new employments in the community, stimulate tourism, recreative fishing, affecting positively the local economy. In the power plant, educational projects such as pisciculture, agriculture, environment preservation, protection of species likely to extinction, rational use of water or electrical energy amongst others, can be developed for the population in partnership with the local institutions. Educational projects focusing the importance of preservation consciousness and the rational use of available resources are fundamental to reduce the system expanding needs, saving labor and operational costs and reducing the social-environment impacts, thus improving the population living quality.

Repowering of power plants is an enterprise that places clean, renewable energy in the nation electrical system, contributing to retard or even deactivate the thermoelectric energy based on combustible fossil, avoiding the GHG emission produced by its combustion.

\section{Carbon Credits}

Enterprisers interested in investing on repowering projects can acquire benefits in the carbon credit market, thus reducing the paying-off time of the invested capital. The Kyoto Treaty establishes that the developed countries should reduce the GHG emissions to $5,2 \%$ in relation to what was in 1990 between the period of 20082012 [5]. The Clean Development Mechanism allows that the developed countries can invest on projects of reduction of GHG in developing countries, generating carbon credits at a marginal cost for reducing emissions much less than it would be at their own territories. A ton of carbon gas surpassing that limit costs about US $\$ 40$ while a ton of carbon credit is much less that that limit, circa US\$5 [6]. The representation base of one carbon credit is the ton of equivalent $\mathrm{CO}_{2}\left(\mathrm{tCO}_{2} \mathrm{e}\right)$, being that all the other greenhouse gases are converted for mass units of $\mathrm{CO}_{2}$.

In countries like Brazil, the income received from the marketing of carbon credit would bring additional benefits due to the fact that the trade is done in strong currency (US dollars or Euro), protecting the debt against the nation currency devalue (R\$). Besides the possibility of earning money negotiating with the carbon credit papers, enterprisers that promote repowering can count in its balance with a stamp of sustainable development from the United Nations and present a better image before this emerging market [6].

With the purpose of demonstrating the attractive aspects of repowering, this work presents a case study of a SHPP, whose technical characteristics are discussed below, where the philosophy of decision undertaking about the viability of the project is based on the technicaleconomical analysis as much as in the socialenvironmental benefits that the enterprise offers.

\section{Case Study - SODRE SHPP}

The Sodre plant is located in the district of Pilões, in the town of Guaratinguetá, State of São Paulo, in Brazil. The Sodre was inaugurated in 1912 and deactivated in 1982 [7]. From 1986 to 1990, it was reformed and brought back to power production from 1990 to 1992 , when it presented technical problems that didn't attract investments to your repair, due to little energy that joined to the electric system. The possibility to repower the plant to increase their generation capacity and to improve their operation conditions wasn't considered at that time. Not even the environmental and social aspects were observed.

This case study presents an evaluation of the hydraulic potential of the river that feeds the plant, as well as it analyzes the economical viability of this repowering project considering the acquired benefits with the commercialization of carbon credits, presenting the involved costs and the investment paying-off time. 


\section{A. Power Plant General Characteristics}

The present proprietor of Sodre SHPP is EMAE (Metropolitan Company of Water and Energy). The hydraulic potential that supplies the plant comes from the Rio Piagui, which belongs to the hydraulic basin named Rio Paraiba do Sul. Sodre's dam reservoir is of small capacity, about $4.500 \mathrm{~m}^{3}$. The height between the plant and the capture is about 123 meters. The plant has 3 generator units of $200 \mathrm{~kW}$ each, totaling $600 \mathrm{~kW}$ installed power [7].

\section{B. Evaluation of the Real Generating Capacity of the Power Plant}

The evaluation of Rio Piagui's hydraulic potential is necessary in order to verify the electrical energy generating capacity of the plant. To this scope, it is necessary to determine the maximum and minimum flow which can be regulated in Rio Piagui. Table I presents the monthly mean flow by year and the monthly mean flow between 1980 and 2002, obtained from the daily mean flow registered.

TABLE I - Monthly Mean Flow between 1980 and 2002 [8].

\begin{tabular}{|c|c|c|c|c|c|c|c|c|c|c|c|c|}
\hline \multicolumn{13}{|c|}{ Monthly Mean Flows ( $\left.\mathrm{m}^{3} / \mathrm{s}\right)$} \\
\hline Year & Jan & Feb & Mar & Apr & May & Jun & Jul & Aug & Sep & Oct & Nov & Dec \\
\hline 1980 & 7,73 & 6,47 & 4,16 & 7,23 & 3,32 & 2,66 & 1,92 & 1,89 & 1,67 & 2,32 & 5,49 & 5,50 \\
\hline 1981 & 9,89 & 5,04 & 6,81 & 4,58 & 3,10 & 2,71 & 2,08 & 1,69 & 1,24 & 3,29 & 5,11 & 6,20 \\
\hline 1982 & 9,75 & 5,26 & 13,48 & 8,10 & 4,18 & 3,40 & 2,71 & 2,50 & 1,69 & 2,79 & 1,99 & 5,53 \\
\hline 1983 & 11,85 & 10,09 & 11,40 & 7,29 & 5,67 & 9,63 & 4,08 & 2,71 & 7,98 & 6,89 & 5,33 & 10,67 \\
\hline 1984 & 4,65 & 3,33 & 3,29 & 3,75 & 3,50 & 1,79 & 1,36 & 1,79 & 1,66 & 0,82 & 1,30 & 5,47 \\
\hline 1985 & 15,89 & 16,03 & 15,58 & 6,65 & 3,72 & 2,95 & 1,87 & 1,32 & 2,23 & 1,19 & 3,81 & 6,61 \\
\hline 1986 & 5,67 & 7,88 & 14,47 & & 4,77 & 2,49 & 2,60 & 2,56 & 1,74 & 1,47 & 1,91 & 6,82 \\
\hline 1987 & 8,09 & 4,84 & 4,26 & 7,96 & 5,17 & 4,15 & 2,74 & 2,19 & 2,66 & 3,00 & 2,07 & 8,30 \\
\hline 1988 & 7,62 & 12,84 & 11,63 & 7,24 & 6,15 & 4,03 & 2,59 & 1,81 & 2,14 & 4,57 & 3,42 & 5,59 \\
\hline 1989 & 9,24 & 10,92 & 13,69 & 5,00 & 3,57 & 3,22 & 2,64 & 2,00 & 1,94 & 1,60 & 9,85 & 9,75 \\
\hline 1990 & 5,64 & 4,79 & 5,52 & 3,76 & 2,66 & 1,84 & 1,83 & 2,23 & 2,80 & 2,89 & 2,38 & 3,29 \\
\hline 1991 & 19,67 & 10,67 & 15,90 & 9,79 & 4,81 & 3,48 & 2,43 & 2,18 & 1,67 & 5,36 & 2,55 & 3,07 \\
\hline 1992 & 9,38 & 4,28 & 4,85 & 6,08 & 3,57 & 2,23 & 2,10 & 2,09 & 11,19 & 7,21 & 8,51 & 111,44 \\
\hline 1993 & 5,82 & 18,33 & 13,16 & 3,25 & 3,14 & 2,53 & 1,82 & 1,53 & 2,52 & 2,70 & 1,44 & 4,32 \\
\hline 1994 & 6,09 & 2,81 & 6,31 & 9,33 & 4,59 & 2,91 & 2,06 & 1,51 & 1,23 & 1,39 & 4,08 & 7,04 \\
\hline 1995 & 9,22 & 14,86 & 8,73 & 2,98 & 3,48 & 2,93 & 2,85 & 1,44 & 2,10 & 10,82 & 6,28 & 6,27 \\
\hline 1996 & 11,41 & 7,91 & 11,56 & 5,79 & 3,40 & 2,72 & 2,17 & 1,85 & 6,51 & 3,06 & 9,81 & 8,46 \\
\hline 1997 & 7,32 & 5,42 & 8,42 & 4,41 & 2,58 & 4,18 & 1,91 & 1,20 & 1,33 & 2,01 & 6,90 & 4,19 \\
\hline 1998 & 9,51 & 9,15 & 9,39 & 4,12 & 2,06 & 1,25 & 1,01 & 1,89 & 2,46 & 5,50 & 2,83 & 5,72 \\
\hline 1999 & 20,89 & 14,69 & 14,90 & 8,99 & 4,28 & 4,65 & 3,92 & 3,38 & 3,14 & 2,55 & 3,83 & 9,47 \\
\hline 2000 & 15,73 & 14,86 & 14,81 & 9,74 & 3,35 & 3,08 & 4,24 & 4,59 & 3,86 & 3,38 & 5,19 & 7,19 \\
\hline 2001 & 14,54 & 8,44 & 6,19 & 7,23 & 3,01 & 1,94 & - & - & 4,13 & 4,50 & 4,62 & 13,25 \\
\hline 2002 & 10,32 & 11,28 & 11.99 & 5,32 & 3,66 & 2,02 & & - & & & 5,64 & 12,34 \\
\hline Qme & 7,61 & 6,78 & 7,44 & 4,47 & 2,83 & 2,35 & 1,64 & 1,43 & 2,19 & 2,56 & 3,37 & 5,37 \\
\hline
\end{tabular}

To proceed with the analysis, one needs to determine the typical year [9] which presents the minimum amount value from equation (1), representing in the historical series of data, the real year that mostly approach the mean flow value is:

$$
\sum_{i=1}^{12}\left(Q_{m i}-Q_{m e}\right)^{2}
$$

Being $Q_{m i}$ the monthly flow (in $\mathrm{m}^{3} / \mathrm{s}$ ) and $Q_{m e}$ the arithmetical mean of monthly flow between 1980 and 2002 (in $\left.\mathrm{m}^{3} / \mathrm{s}\right)$, obtained in Table I

The typical year found was 1998. The graphics presented in Figure 1 shows that the maximum regulated flow (the arithmetical mean of monthly flow in 1998) is $\bar{Q}=4,57 \mathrm{~m}^{3} / \mathrm{s}$ and the minimum flow (minimum registered in 1998) is $Q_{\text {min }}=1,01 \mathrm{~m}^{3} / \mathrm{s}$.

Considering the maximum regulated flow of $4,57 \mathrm{~m}^{3} / \mathrm{s}$, the reservoir volume of $46.582 \mathrm{~m}^{3}, 0,9$ efficiency and the height of $123 \mathrm{~m}$ between the plant and the capture, the generation capacity of the plant would reach $5 \mathrm{MW}$.
However, it is inviable to produce that power because the Sodre plant reservoir is only $4.500 \mathrm{~m}^{3}$. To reach that power capacity of $5 \mathrm{MW}$ it would be necessary to expand the reservoir, which would imply in higher environmental impacts and raising the costs for repowering, amidst other negative aspects.

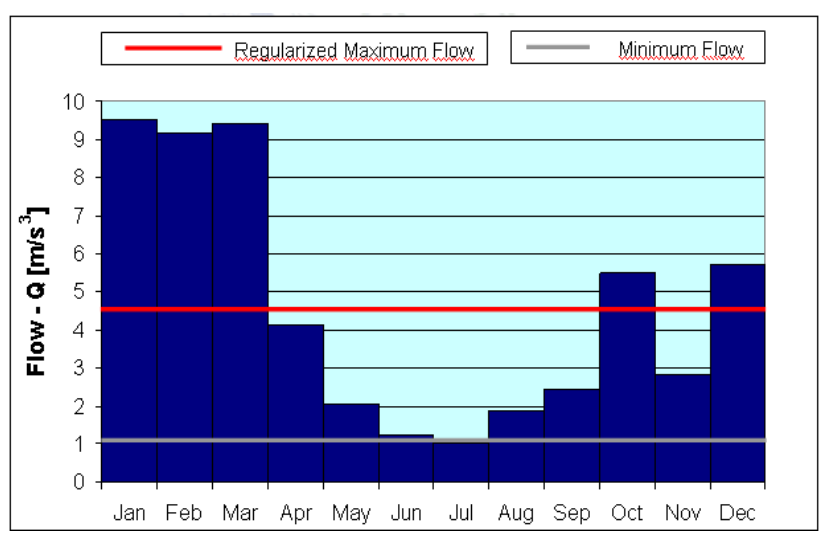

Figure 1 - Monthly Mean Flow in 1998

The most viable way is to analyze the power plant from the water fillet standpoint, considering a minimum flow 
of $1,01 \mathrm{~m}^{3} / \mathrm{s}$, a reservoir volume of $4.500 \mathrm{~m}^{3}, 0,85$ efficiency and a height of $123 \mathrm{~m}$. In these terms, the available power is $1 \mathrm{MW}$.

Then, one verifies that it is possible to make a better use of the hydraulic potential of the Rio Piagui, increasing the generation power of the plant up to $75 \%$ from its present capacity, considering it as a water fillet power plant. Once guaranteed that increase in the generation capacity, it is reasonable to substitute those three 200 MW generators for others of $350 \mathrm{MW}$ each, voltage and speed regulators should also be substituted to adapt the power plant to the new generator conditions.

\section{Carbon Credits created by the Plant Repowering}

In Brazil, though the largest amount of power generated in the country is based on hydraulic resources, most of the low cost investment in power plants is exhausted. Thus, it arises the possibility of investing in non-renewal sources as the thermoelectric plants. As a thermoelectric generator uses combustible fossil to operate, those companies have to spend higher operational costs in comparison to a hydroelectric generator. As a result, it is probable that they become substituted by any hydroelectric connected to the net. In this case, repowering and reactivation of Sodre SHPP is a valid alternative to reduce the pollution created by GHG by substituting a thermoelectric plant which burns combustible fossil to supply energy to an interconnected net.

In order to obtain the exact quantity of GHG reduction obtained through Sodre repowering, it was necessary to know the base line to be used in order to determine the obtained return with the marketing of carbon credits. The baseline is $\mathrm{kWh}$ produced by the renewal generator unit, multiplied by an emission coefficient (measured in $\mathrm{kgCO}_{2} \mathrm{e} / \mathrm{kWh}$ ) which is calculated by the mean of the "approximate operating margin" and "the construction margin", [10] where:

(i) The "approximate operating margin" is the proportional mean of emissions (in $\mathrm{kgCO}_{2} \mathrm{e} / \mathrm{kWh}$ ) of all the generating sources that supply the system, excluding the generation: solar, wind, nuclear, hydraulic, geothermal, and low cost biomass [10];

(ii) The "construction margin" is the proportional mean of emissions (in $\mathrm{kgCO}_{2} \mathrm{e} / \mathrm{kWh}$ ) of recent capacity additions to the system. This mean is calculated based on $20 \%$ of the total year (in $\mathrm{MWh}$ ) of the generation realized by the most recent plants, or based on the total year generation of 5 most recent plants. The base that represents the greatest generation is applied in the calculus [10].

Table II presents the obtained data from the National Dispatching Center and the baseline calculated for the interconnected Brazilian system (South / Southeast / Centerwest), as the Sodre SHPP is located in the State of Sao Paulo, Brazilian Southwest region.
TABLE II - Baseline Calculus of the Brazilian Integrated System (South / Southeast / Centerwest) [10]

\begin{tabular}{|c|c|c|}
\hline Year & $\begin{array}{c}\text { Operating Margin - OM } \\
\text { (tCO2e/MWh) }\end{array}$ & $\begin{array}{c}\text { Generation Total } \\
\text { (MWh) }\end{array}$ \\
\hline $\mathbf{2 0 0 2}$ & 0,9304 & 276.731 .024 \\
\hline $\mathbf{2 0 0 3}$ & 0,968 & 295.666 .969 \\
\hline $\mathbf{2 0 0 4}$ & 0,9431 & 301.422 .617 \\
\hline & Mean $(\mathbf{2 0 0 2 - 2 0 0 4 ) = 0 , 9 4 7 2}$ & Total = 873.820.610 \\
\hline & & \\
\hline & $\mathbf{B a s e l i n e}$ & $\begin{array}{c}\text { Construction Margin - CM } \\
\text { (tCO2e/MWh) }\end{array}$ \\
\hline \multirow{2}{*}{$\mathbf{O M}^{*} \mathbf{0 , 5 + \mathbf { C M }} \mathbf{0 , 5}$ (tCO2e/MWh) } & $\mathbf{0 , 1 2 5 5}$ \\
\hline & $\mathbf{0 , 5 3 6 4}$ & \\
\hline
\end{tabular}

Considering that Sodre SHPP can furnish a total installed capacity of $1050 \mathrm{kVA}$ after repowering, the power factor of the generators is 0,92 and that the firm demand of energy is about $900 \mathrm{~kW}$, the total yearly produced energy by the power plant is circa $7.884 \mathrm{MWh}$. The baseline being of $0,5364 \mathrm{tCO}_{2} \mathrm{e} / \mathrm{MWh}$ and once the repowered plant be connected to the electrical integrated net, it will generate an estimated annual reduction of $4.229 \mathrm{tCO}_{2} \mathrm{e}$. Furthermore, if we consider that those carbon credits be commercialized until 2012, the final year estipulated by the Kyoto Treaty requiring that developed countries fulfill their compromise to reduce the GHG emissions, the total reduction will be approximately $29.603 \mathrm{tCO}_{2} \mathrm{e}$ in seven years. Nowadays, a ton of carbon credit costs about US\$5. Hence, the marketing of credits obtained by the Sodre SHPP repowering until 2012 will provide extra revenue of about US\$148.000.

\section{Economical Viability}

The costs of the main components needing substitution are:

\begin{tabular}{ll}
3 - 350kVA generators & US\$ 31.236 \\
2 - 500kVA transformers & US\$ 14.368 \\
3 - Voltage regulators & US\$ 1.800 \\
3 - Speed regulators & US\$ 2.160 \\
Other accessories & US\$ 15.200 \\
\hline Total cost & US\$ 64.764
\end{tabular}

Note: the above values were furnished by WEG Industries

Being US\$27,4/MWh the electrical energy selling tariff and US $\$ 2,12 / \mathrm{kW}$ the demand tariff [11], Sodre SHPP can produce energy monthly with earnings of approximately US\$21.600. The monthly income obtained by the carbon credit marketing is about US\$1.760. If the plant presented an operational cost of US\$14.000 and an estimated paying-off of US\$3.600, taking into account a monthly interest of $3 \%$, the paying-off time for the invested capital in the repowering of the plant would be approximately 4 years and 6 months, which indicates that repowering is economically viable.

The income obtained by the carbon credit marketing is free from any cost in order to maintain the condition that grants such benefit, as the hydroelectric power plant is characterized as a clean and renewable source of energy that does not pollute the atmosphere. Therefore, if that income weren't considered in the calculus of the economical viability, the monthly value destined for the investment paying-off would be just US\$1.840, which 
would result in a return time of about 6 years and 8 months, thus placing the undertaking less attractive to the investors.

As for the social aspects, repowering of hydroelectric power plants can produce benefits by means of an incentive to tourism, to the commerce, to new jobs, affecting in a positive way the economy of the region where they are inserted. Educational projects can be developed to the community at the power plant. Environment preservation can be explored, for instance, as a program to volunteer reforest which can be another source for obtaining carbon credit. Now, there is still a question to settle: "How to make those social benefits converted into values to be deduced from the repowering costs?" This is a challenge that, though not even being quantified in this work, should not be disregarded in the decision undertaking about the viability of repowering projects.

\section{Conclusion}

The proposal of this work is to demonstrate that repowering of hydroelectric plants is an enterprise totally viable, in order to expand the electrical system generating capacity necessary to face the growing demand of energy in Brazil, thus contributing at the same time, to the environmental sustenance, socially and economically. Particularly, the small hydroelectric power plants represent an important potential to be explored, due to advantages they offer when compared with great hydroelectric utilization and to the significant number of small plants that are nowadays out of operation or even operate below its generating capacity. The case study shows that repowering Sodre SHPP can provide a gain up to $75 \%$ of the installed power, maintaining the plant at water fillet. This result indicates that repowering of small hydroelectric power plants is an excellent alternative to increase the offering of electrical power in a short time, reducing the predictable necessity of electrical power expansion throughout the nation.

An analysis has been presented demonstrating the technical-economical viability of the repowering project in which, besides the expenses of a few equipments and the commercial prices of electrical energy, there were also considered the social and environmental benefits that the enterprise can provide, mainly as refers to the generation and marketing of the carbon credits. The income obtained by the carbon credits promotes a reduction of more than 2 years in the invested capital paying-off. It is also forecast for the next years a significant valuation for a ton of carbon credit caused by the shortage of time to comply with the aim to reduce the greenhouse gases (GHG), as required to the developed countries by the Kyoto Treaty. This expectation, together with the fact that the carbon credits are dealt with in strong currency, it represents another attractive enterprise for the investors in electrical energy and should make part of all studies of economical viability of small hydroelectric power plant repowering projects.

https://doi.org/10.24084/repqj04.293
The social benefits obtained with repowering projects, though not quantified in this work, should not be disregarded in the decision undertaking about the viability of this kind of enterprise. The repowering of deactivated power plants affects positively the economy of the region where they are inserted, stimulating tourism, the commerce, creating new jobs, expanding the city tax collect which can be applied for a better community living quality. Educational projects can likewise be developed at the power plant, thus exerting the fundamental social roll in the formation of conscious citizenship as for questions involving energy and environment, so to partake effectively for a sustained development. If compatible values were to be attributed to those benefits, the economical viability of the repowering projects would become, without any doubt, much more attractive.

\section{Copyrights}

The authors are the only responsible for the printed material in this work.

\section{References}

[1] C. Bermann, G. S. Rocha and J. R. C. Veiga, "A Repotenciação de Usinas Hidrelétricas como Alternativa para o Aumento da Oferta de Energia no Brasil com Proteção Ambiental", São Paulo (2004), pp. 7, 9, 16, 17.

[2] I. M. Filho and W. R. Zanin, "Viabilização de PCHs Conexão Elétrica", Centro Nacional de Referencia em Pequenas Centrais Hidrelétricas, pp. 18. Available: http://www.cerpch.unifei.edu.br/artigos_tec/pdf/tema01/re v17_pag17a19.pdf

[3] "Banco de Informações de Geração", ANEEL - Agência Nacional de Energia Elétrica. Available: http://www.aneel.gov.br

[4] R. A. Hinrichs and M. Kleinbach, "Energy: its use and the environment", Ed. Pioneira Thomson Lerning, São Paulo (2003), pp. 328.

[5] B. Eliasson, "Working Together on Global Climate Problems", IEEE Power Engineering Review, March 2001, pp. 4.

[6] "Klabin e Aracruz: Elétricas apresentam Projetos para Mercado de Carbono", Associação Brasileira de Grandes Consumidores Industriais de Energia. Available: http://www.abrace.org.br/salaimprensa_noticia_associados. asp?id=179

[7] C. A. Amaral and F. A. A. Prado Jr., "Pequenas Centrais Hidrelétricas no Estado de São Paulo", CSPE, São Paulo (2000), pp. 55.

[8] "Registro das Vazões Médias Diárias do Rio Piagüi", DAEE - Departamento de Águas e Energia Elétrica. Available: http://www.sigrh.sp.gov.br/cgibin/bdhm.exe/flu

[9] Z. Souza, "Centrais Hidrelétricas, Dimensionamento de Componentes", Editora Edgar Blücher, São Paulo (1992), pp. 100.

[10] "Documento de Concepção do Projeto Simplificado para Atividade de Projeto de Pequena Escala", MDL Comitê Executivo, 27 Sept 2005, pp. 10, 25, 26, 35.

[11] "Resolução Homologatória № 139, de 27 de Junho de 2005", ANEEL - Agência Nacional de Energia Elétrica. Available: http: //www. aneel.gov.br

RE\&PQJ, Vol. 1, No.4, April 2006 